\title{
Ruptura, liberación y necesidad. El semanario Compañero y una lectura sobre la revolución en los sesenta del peronismo
}

\author{
[Rupture, Liberation and Necessity. The Weekly Compañero and a Reading \\ about the Revolution in the Sixties of Peronism]
}

\author{
Andrés N. Funes \\ (CONICET - Universidad Nacional de San Martín) \\ funes.andres.n@gmail.com
}

\begin{abstract}
Resumen:
Numerosas son las investigaciones académicas que buscaron comprender los contornos que adoptó el término revolución en las organizaciones políticas argentinas de finales de los sesenta y principios de los setenta, pertenecientes tanto a la izquierda peronista como también a la marxista. Sin embargo, un breve buceo por la bibliografía permite sostener que han escaseado las pesquisas orientadas a examinar los sentidos que el concepto de revolución tomó para el peronismo de los primeros años de la década del sesenta. Consciente de esta vacancia, este trabajo busca desentrañar los sentidos y significaciones que tomó el término revolución para un sector del peronismo, los "duros" o "combativos", que se expresaban a través del semanario político Compañero a comienzos de los años sesenta. El artículo se ofrece como una vía de entrada inicial para comprender y complejizar el discurrir del peronismo en aquellos años.
\end{abstract}

Palabras clave: Revolución - Liberación Necesidad - Compañero - Años sesenta

\begin{abstract}
:
Numerous are the academic researches that sought to understand the contours adopted by the term revolution in the Argentine political organizations of the late sixties and early seventies, belonging to both the Peronist and the Marxist left. However, a brief exploration through the literature suggests that there has been a lack of research aimed at examining the meanings that the concept of revolution took for the Peronism of the early 1960s. Aware of this vacancy, this work seeks to unravel the meanings that took the term revolution for a sector of Peronism, the "duros" or "combativos", which were expressed through the political weekly Compañero at the beginning of the sixties. The article is offered as an initial entry point to understand and complicate the course of Peronism in those years
\end{abstract}

Keywords: Revolution - Liberation - Necessity Compañero - Sixties

\footnotetext{
Recibido: 8/12/2018

Evaluación: 11/3/2019

Aceptado: 3/4/2019
}

\author{
Anuario de la Escuela de Historia Virtual - Año 10 - N 15 - 2019: pp. 27-50. \\ ISSN: 1853-7049 \\ http://revistas.unc.edu.ar/index.php/anuariohistoria
}




\section{Ruptura, liberación y necesidad. El semanario Compañero y una lectura sobre la revolución en los sesenta del peronismo}

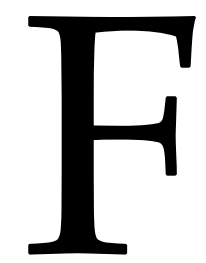

abio Wasserman (2008), en su trabajo sobre el término revolución en el Río de la Plata del siglo XIX, señala que el concepto adquirió una gran difusión tras la Revolución Francesa, la crisis de la Monarquía española y la Revolución de Mayo. Como muestra a partir del prólogo de Mariano Moreno al Contrato Social, el término tomó un "cariz positivo al expresar la posibilidad de profundos cambios de orden político, social, moral y cultural" (Wasserman, 2008, p. 162). Al decir del historiador, gran parte de la responsabilidad en la tonalidad positiva que adquirió la palabra se debió a que ella permitió comprender un proceso caótico, surcado por cambios, marchas y contramarchas. En este sentido, entonces, "contribuyó a articular un nuevo marco de inteligibilidad en los que esos sucesos atenuaban su carácter contingente y cobraban mayor sentido al formar parte de un proceso de cambio histórico" (Wasserman, 2008, p. 162).

No sería descabellado sentenciar que el término siguió funcionado de una manera similar con el correr posterior de la historia argentina. Haciendo un simple ejercicio memorístico, entre la Revolución de Mayo de 1810 y la autodenominada Revolución Argentina de 1966, existieron al menos cuatro fenómenos que se presentaron a sí mismos como revolucionarios; como experiencias políticas que decían inaugurar una nueva época, poniendo los cimientos de un nuevo origen a través de la transformación del orden dado: la Revolución de 1880, la Revolución del Parque de 1890, la Revolución del 43 y la Revolución Libertadora de 1955. Aparecen aquí algunos ecos de lo que ha marcado Hannah Arendt (2012 [1963]): durante el curso de las revoluciones de siglo XVIII, los hombres comenzaron a considerar que un nuevo origen podía constituir un fenómeno político, resultado de aquello que ellos mismos hicieran y de lo que conscientemente se propusieran. ${ }^{1}$

A este respecto, se pueden mencionar también algunas de las características, las más relevantes para este artículo, que Reinhart Koselleck ([1979] 1993) asoció al moderno concepto de revolución. Además de su concentración en un "singular colectivo", que hacía que todas las revoluciones individuales parecieran unificarse en La Revolución,

\footnotetext{
${ }^{1}$ Aquí bien vale una aclaración. Si bien en este trabajo tendrán un rol fundamental las reflexiones que el pensamiento arendtiano realizó en derredor del fenómeno revolucionario, ello no cercena otros de acercamientos teóricos posibles. Es el caso, por ejemplo, de enfoques de tipo marxistas como los que han elaborado Perry Anderson (1984 y 2010) o Neil Davison (2013). Toda decisión teórico-metodológica conlleva algo de arbitrariedad, por lo que futuras lecturas a la luz de la teoría marxista deberán completar las aserciones lanzadas a la luz de la teoría arendtiana.
} 
tras el cismo de 1789, para Koselleck, el marco conceptual de la revolución condujo a: 1) la intensificación de la experiencia de la "aceleración" (p. 76); 2) la transformación del concepto en uno de "perspectivista de carácter filosófico-histórico, que indicaba una dirección sin retorno" (p. 77); 3) el paso de la revolución política a la revolución social, donde la meta de la primera pasa a ser la "emancipación social de todas las personas, la transformación de la propia estructura" (p. 78); y 4) su tendencia a la mundialización ("revolución mundial", característica espacial) y a la permanencia ("revolución permanente", característica temporal), hasta que se hayan logrado sus fines (p. 79).

Teniendo esto en cuenta, el artículo examina el concepto de revolución en un semanario político vinculado al peronismo "revolucionario" y a los sectores sindicales "duros" o "combativos", Compañero, en los años sesenta de Argentina. Aquí el significante revolución es presentado como la meta deseada, el objetivo al que debía apuntar el movimiento peronista. Determinar las aristas que ofreció el concepto de revolución en tanto instancia fundamental de la construcción del futuro deseado (Aboy Carlés, 2001) puede arrojar luz sobre el proyecto político delineado en el semanario y sobre aquel que presentó una parte no menor del movimiento peronista durante el exilio de Perón. Sin embargo, debe tenerse en cuenta que, al igual que sucede con otros términos - por caso, pueblo, democracia, Nación, para mencionar los más relevantes-, el de revolución es un significante en disputa. En otras palabras, opera como aquello que Ernesto Laclau (1996) denominó "significante vacío": términos que, vaciándose tendencialmente de su significado particular, pueden ser articulados -y por ello resignificados- en proyectos hegemónicos diversos e incluso opuestos. Así, por ejemplo, el significante "revolución" no solo aparece simultáneamente en Compañero y en el Boletín Informativo Semanal de las Actividades de la Confederación General del Trabajo -órgano oficial de la Confederación General del Trabajo (CGT) y por ello objeto de polémicas con el semanario-, sino que también ambas publicaciones significan la "revolución" de distintos modos.

Retomando el hilo propuesto en este artículo, ¿qué fue Compañero y por qué vale la pena detenerse en la concepción que circuló allí sobre el hecho revolucionario? Para empezar, se trató de un semanario político dirigido por el médico, periodista y antiguo militante del Movimiento Universitario Reformista (MUR), Mario Valotta. Los 79 números que conforman su "primera época" 2 fueron editados entre junio de 1963 y abril de 1965. El 5 de agosto de 1964, en el marco del plenario desarrollado en el sindicato de Calzado de la ciudad de Buenos Aires que constituyó el Movimiento Revolucionario Peronista (MRP), el semanario fue elegido allí "por aclamación" como el "vocero" del recién formado movimiento. Esto es, como el órgano de "expresión actualizada del

\footnotetext{
2 Valotta intentó reeditar el semanario en dos ocasiones más. La primera, entre noviembre de 1968 y enero de 1970. Junto a Mario Pérez dirigieron una "segunda época" de Compañero que contó con tan solo cinco números. Luego, entre octubre y noviembre de 1973, Valotta reeditó el semanario. Este último intento tuvo dos números. Para ahondar en los pormenores de las tres ediciones de Compañero, se recomienda Facundo Carman (2015).
} 
pensamiento de General Perón”. El MRP constituyó, a pesar de su breve existencia, ${ }^{3}$ el intento más serio llevado a cabo por los sectores "duros" del peronismo en los primeros años sesenta por disputarle poder al dirigente metalúrgico Augusto Timoteo Vandor. Para Compañero el haber sido ungido como portavoz del MRP significó insertarse de lleno en el peronismo. El caso del propio Valotta, por ejemplo, es aleccionador en este sentido: de militante reformista en su juventud a "peronista revolucionario" en su adultez, tras una breve adscripción al frondizismo. Si bien es cierto que el acercamiento de Valotta al movimiento peronista es anterior tanto a la aparición de Compañero como también a la creación del MRP, ${ }^{4}$ la participación activa que tuvieron Valotta y gran parte de su equipo editorial en la conformación Movimiento Revolucionario Peronista puede ser entendida como una suerte de peronización temprana para un gran número de lectores de Compañero en estos primeros momentos de la década del sesenta. Peronización, debe decirse, que iba más allá de manifestar adhesión al peronismo. Se trataba de tomar partido e intervenir en las querellas que sacudían al movimiento liderado por Perón, de restituir el carácter "revolucionario" del peronismo ${ }^{5}$ en un periodo donde la estrella de Vandor amenazaba con poner en jaque el liderazgo a distancia del caudillo.

Un hecho indiscutible, y que abona el intento que este artículo quiere llevar a cabo, es que usualmente los análisis sobre los significados que adquirió el término revolución en la segunda mitad del siglo XX en la Argentina parecen circunscribirse casi con exclusividad a los años setenta. Es el caso, por ejemplo, de trabajos clásicos como los de Claudia Hilb y Daniel Lutzky (1984) o el de María Matilde Ollier (1986). En este sentido,

\footnotetext{
${ }^{3}$ Para Daniel James (1990), pocos días después del 5 de agosto de 1964, Vandor y otros dirigentes sindicales afines, preocupados ante la conformación del MRP, viajaron a Madrid a encontrarse con Perón. Volvieron de "Puerta de Hierro" con una lisa y llana desautorización del caudillo al recién formado grupo, lo que significaba virtualmente su muerte. En cambio, para Carlos Gaitán (2014), partícipe activo del MRP, la vida del Movimiento que se formó ese 5 de agosto se extendió hasta entrados los setenta, organizando regionales en buena parte de la Argentina.

${ }^{4} \mathrm{Al}$ convertirse en "subdirector a cargo de la dirección" de Democracia, las páginas de este periódico son testigos de una lenta, progresiva pero cuidadosa aproximación al peronismo, que no solo llevó a la clausura del diario en julio de 1962 sino que también lo condujo a Valotta a pasar siete días detenido. Su posterior aventura editorial fue el semanario 18 de Marzo, antecedente inmediato de Compañero, publicación de explícita vinculación con el sector "duro" del peronismo liderado por dirigente textil Andrés Framini. Este semanario no corrió mejor suerte. Fue clausurado por el gobierno de José María Guido en febrero de 1963, tras la salida de su número 9. Una breve síntesis de las características de Democracia y 18 de Marzo puede encontrarse en Carman (2015).

${ }^{5}$ Mucho se puede decir acerca de los trabajos académicos que pretendieron encontrar en el fenómeno peronista un hecho revolucionario/rupturista o una experiencia reformista/continuadora con su pasado inmediato. Mariano Plotkin (1991), por ejemplo, sintetiza y analiza las múltiples interpretaciones académicas que se han formulado acerca de los orígenes del peronismo. Más recientemente, Julián Melo (2009), enfocándose en la glosa de Perón, ha señalado el doble movimiento de heredad e innovación que operó en su discurso. No habría allí, para Melo, una demonización de todo pasado sino tan solo de aquel que trastocó el normal transcurrir evolutivo. En virtud de ello, el hecho revolucionario que el acaecer peronista venía a significar, según encuentra el autor en los discursos de Perón, no parecía no ser otra cosa que el recolocar a la Argentina por una presunta senda perdida. En otras palabras, ni la ruptura ni la continuidad fueron totales. Esta idea es fundamental para el artículo que aquí se elabora. Más que pensar totalidades, se busca cazar tensiones; esto es, señalar rupturas y/o continuidades de sentidos.
} 
y a pesar de algunos interesantes trabajos realizados en épocas más recientes, ${ }^{6}$ podría sostenerse con seguridad que han escaseado las investigaciones orientadas a examinar los sentidos que el concepto de revolución tomó para el peronismo de los primeros años de la década del sesenta. Precisamente, el artículo que aquí se presenta busca contribuir a esto. Este examen sobre la "revolución" en el semanario Compañero ofrece una vía de entrada para iluminar el discurrir peronista del peronismo en aquellos años inaugurales de los sesenta.

\section{Entre La Falda y Huerta Grande, ¿el socialismo?}

En agosto de 1957 la Confederación General del Trabajo (CGT) y las 62 Organizaciones Peronistas convocaron a todas las regionales a la ciudad cordobesa de La Falda. La seccional cordobesa de la CGT y "las 62" dieron a conocer allí lo que se llamó el "Programa de La Falda". Dividido en tres apartados que recordaban las banderas fundamentales del peronismo -independencia económica, justicia social y soberanía política-, la proclama no solo hacía referencia a las políticas económicas y sociales que implementó el peronismo - “Control estatal del comercio exterior sobre las bases de la forma de un monopolio estatal", "Desarrollo de la industria liviana adecuada a las necesidades del país", "Nacionalización de las fuentes naturales de energía", entre otras- sino que también abogaba en favor de, por ejemplo, la "Liquidación de los monopolios extranjeros de importación y exportación", la “Expropiación del latifundio y extensión del cooperativismo agrario" y la "Solidaridad de la clase trabajadora en las luchas de liberación nacional de los pueblos oprimidos" (Baschetti, 2012, pp. 123-125). Aun cuando el Programa se presentaba como una respuesta a la derogación de la Constitución peronista de 1949, el nombre de Perón no figuraba en la fundamentación y menos aún se pedía su retorno. No es casual esta ausencia. Como recuerda James McGuire (2004 [1993]), muchos dirigentes sindicales del periodo que creían en la negociación con el régimen militar del 55, eran puestos en un serio dilema "cuando Perón los urgía a lanzar una lucha total para crear las condiciones necesarias para su retorno a la Argentina" (p. 169). Más aún, Daniel James (1990) señala que aún con la intensa represión de la "Libertadora" a cuesta, no pudo quebrarse la "capacidad de los sindicatos peronistas para actuar como fuerza organizadora de la totalidad del peronismo" (p. 112), como puede verse, por ejemplo, en el papel central que tuvieron las 62 Organizaciones en la reorientación de los votos en las elecciones de febrero de 1958.

Cuatro años después, en junio de 1962, se celebró en la localidad cordobesa de Huerta Grande un plenario nacional de "las 62". Allí se establecieron diez puntos de lo que sería denominado el "Programa de Huerta Grande". Si bien el contenido programático no cambió sustancialmente respecto al de "La Falda", resulta interesante reparar en el anteúltimo párrafo del antecedente histórico: "[S]e aprueban como objetivos programáticos a imponer al gobierno los puntos que constituirán una profundización de

${ }^{6}$ Aquí pueden mencionarse, por caso, los trabajos de Juan Bozza (2001 y 2014). 
los contenidos antioligárquicos del Peronismo, de acuerdo con el 'giro a la izquierda' alentado por el General Perón" (Baschetti, 2012, p. 228). Según el dirigente sindical Andrés Framini, "Huerta Grande" fue un producto de Perón al notar que estaban desviándose los principios doctrinarios del peronismo. Precisamente, continuaba el frustrado Gobernador de Buenos Aires, el "giro de izquierda" de Perón no "tenía nada que ver ni con la filosofía marxista ni con la filosofía capitalista" sino que involucraba tan solo un retorno a "principios básicos del movimiento revolucionario peronista" (Calello y Parcero, 1984, p. 55). Es esto lo que le permite asegurar a McGuire (2004 [1993], p. 179) que el giro estuvo más bien orientado a eclipsar la estrella naciente de Vandor que a significar un compromiso real de Perón para conducir al país por la senda socialista. $^{7}$

No es esta la opinión de, por ejemplo, Juan Bozza (2001). Para el historiador platense, el "peronismo revolucionario", esto es, aquellas corrientes influidas por el pensamiento de John William Cooke, pretendía hacer coincidir las vicisitudes de los pueblos del Tercer Mundo con el mundo socialista; los “movimientos de liberación inexorablemente debían transitar hacia el socialismo, una construcción que debía ser el producto de las circunstancias latinoamericanas" (p. 156). A este respecto, para el propio Cooke, la "revolución nacional siempre es en parte socialista, siempre es un paso al socialismo", no pudiendo orientarse nunca al "mantenimiento del «statu quo»" (2014 [1972], p. 524). Si bien el argumento de Bozza es correcto para los grupos ligados al ex delegado personal de Perón, en el semanario Compañero no existió una ligazón entre revolución y socialismo.

Véase cómo aparece en el semanario el concepto de revolución. En dos notas, Framini intentó describir qué significaba. Argüía el dirigente textil:

El peronismo sostiene la necesidad de una Revolución de la sociedad argentina. Una Revolución que comprenda el campo político, económico, jurídico y social. Esta Revolución que propiciamos tiene como objetivos la plena realización de la Nación y del hombre argentino. Dentro del marco de nuestra Doctrina, la necesidad de la Revolución no surge de una elaboración mental ni de una declaración de deseos, sino de la REALIDAD. Es el análisis de la realidad mundial y argentina la que nos permite concluir la necesidad de la Revolución. ${ }^{8}$

Al decir de Framini, la revolución que se piensa desde el peronismo involucraba el trazado de un nuevo "campo político, económico, jurídico y social", terreno fértil en el cual la "plena realización de la Nación y del hombre argentino" podría darse. Aquí

\footnotetext{
${ }^{7}$ En una sintonía similar, Alejandro Schneider (2006) sostiene que Huerta Grande no llevó a cuestionar ni a impugnar el sistema capitalista, produciendo, en todo caso, "enumeraciones propias de la retórica y de la tradición peronista" (p. 188). Podría legítimamente preguntársele al autor si considera que "expropiar a la oligarquía terrateniente sin ningún tipo de compensación" o "implantar el control obrero de la producción", puntos 7 y 8 del mencionado Programa, deberían ser considerados como simples retóricas de la tradición peronista y no, como puede sugerirse, como impugnaciones al capitalismo.

8 “QQué es la revolución?”, Compañero, año 1, nro. 20, 6 de noviembre de 1963, p. 3.
} 
Framini no se apartaba de lo que sostuviera en su famoso discurso ante el Plenario de delegados regionales de la CGT en Huerta Grande, tan solo dos años antes: para solucionar la crisis que pesaba sobre el sistema capitalista la "única solución real está en la transformación profunda de toda la estructura económica, financiera y jurídica: y social política y estatal" (En Callelo y Parcero, 1984, p. 206). Se trataba, continuaba Framini en 1962, de una "transformación revolucionaria, destinada a crear una economía y una democracia social al servicio exclusivo de la comunidad argentina" (Calello y Parcero, 1984, p. 206). Retomando lo dicho por el Secretario General de la AOT en su nota en Compañero, la revolución, ese cambio de estructuras económicas, políticas y sociales se mostraba, gracias a los ejemplos que se sucedían en el mundo, como una necesidad ineludible para la Argentina.

Unas líneas más adelante, en el mismo “¿Qué es la revolución?”, Framini sostenía sin ambages que las revoluciones presentaban un conjunto de leyes:

Estas leyes, extraídas de la experiencia social, no tienen, por supuesto, la rigidez y exactitud de las leyes naturales, pero su conocimiento constituye una herramienta valiosa para establecer puntos de partida, comprender las tendencias de la evolución social y formular hipótesis de trabajo, sujetas luego a la comprobación por la vía de la experiencia revolucionaria (...) [Estas son] 1) El pueblo participa de una manera masiva, directamente, con su acción y no por medio de representantes, en la producción de hechos revolucionarios. Ninguna revolución trascendente (...) se ha producido sin la presencia, en mayor o menor medida, de las masas populares. 2) Cada revolución constituye un fenómeno inédito, un acto de creación del pueblo que la realiza. Ninguna revolución ha repetido los métodos de lucha de las que la han precedido. ${ }^{9}$

Framini aseguraba que las leyes de la revolución, las que permitían la comprensión de los fenómenos políticos y también el diseño de escenarios futuros, eran dos. Por un lado, la participación directa y sin intermediarios del pueblo. En este sentido, continuaba el Gobernador electo de Buenos Aires, no hubo revolución importante que se haya producido "sin la presencia, en mayor o menor medida, de las masas populares". Por el otro, la segunda de las leyes mencionadas por Framini dictaba que la revolución era un hecho inédito, "un acto de creación del pueblo que la realiza". Por lo tanto, ninguna de las revoluciones ocurridas en la Argentina ha "repetido los métodos de lucha" de las anteriores. Esto es, cada una de las revoluciones nacionales sucedidas tuvo elementos originales, introduciendo métodos y concepciones nuevas acerca del modo de llevar adelante la lucha revolucionaria, que, lógicamente, eran desconocidos hasta ese momento.

Dos elementos pueden señalarse de los extractos citados: la necesidad y la novedad del proceso revolucionario. A este respecto, Hannah Arendt (2012 [1963]) señaló que uno de los elementos que ha caracterizado a las revoluciones de finales del siglo XVIII fue la conciencia de que era posible configurar un origen nuevo. Esto es, que podía trazarse

\footnotetext{
${ }^{9}$ Ibidem.
} 
una cesura en el ciclo de la historia e introducir allí un cambio, una novedad. Aquí se produjo, al decir de la teórica política alemana, la transformación del pretérito significado del término revolución como restauración a la revolución como nuevo comienzo. ${ }^{10}$ Como toda concepción revolucionaria que siguió la huella de la Revolución Francesa, la que se vislumbra en Compañero parece estar atravesada por la idea de un cambio, de un quiebre y la introducción de algo nuevo: un fenómeno inédito con métodos no vistos antes, que puede transformar la política, la economía, la sociedad y, además, realizar plenamente a la Nación y a sus hombres.

A su vez, este concepto de revolución está teñida de un componente esencial de los procesos que siguieron a las revoluciones francesa y rusa: la "noción de un movimiento irresistible (...) [que se traduciría] conceptualmente a la idea de la necesidad histórica" (Arendt, 2012 [1963], p. 64). Este era, aseguraba Arendt (2012 [1963]), un resabio del concepto astronómico de revolución que creía en la existencia de una fuerza irresistible -el movimiento rotatorio de las estrellas- que estaba más allá de la voluntad de los hombres. La fuerza de la historia y de la necesidad histórica permitían asegurar a Framini que comenzar la revolución era una necesidad para el peronismo, dictada por la propia circunstancia argentina y también mundial. Necesidad que, como apuntaron ya Ernesto Laclau y Chantal Mouffe (2006 [1985]), tiende a establecer un sentido literal, anulando cualquier variación accidental o fortuita. Esto es, un proceso revolucionario al parecer prefijado y de sentido unívoco.

Ahora bien, la revolución en tanto introducción de la novedad presentaba en el semanario un conjunto de características precisas. Por ejemplo, para un obrero metalúrgico de San Martín entrevistado por Compañero, "la única garantía de la concreción de un cambio de estructuras", ${ }^{11}$ o sea, de la producción del fenómeno revolucionario, estaba dada por la participación física en la conducción del país de los trabajadores. Este pregonado "cambio de estructuras" fue utilizado también por la CGT de aquellos años. Al decir de James (1990), los documentos de la central obrera que comenzaron a aparecer a partir de 1963 “tenían por principal objetivo forjar la imagen de una central obrera técnicamente idónea, que miraba para adelante y era capaz de discutir responsable y científicamente el futuro de la nación" (p. 268). Al reparar en esto, Alain Rouquié (1982) asegura que este "cambio de estructuras" poco tenía que ver con una transformación de las estructuras económicas. El cambio hacía referencia, más bien,

\footnotetext{
${ }^{10}$ Como anotó muy certeramente Reinhart Koselleck: “la revolución ya no regresa, desde entonces [desde la Revolución Francesa], a situaciones o posibilidades pasadas; desde 1789 conduce a un futuro tan desconocido que reconocerlo y tener autoridad sobre él se ha convertido en una tarea constante de la política" ([1979] 1993, p. 75). El autor aprovecha este espacio para agradecer a uno de sus evaluadores anónimos el haberle sugerido sumergirse en el pensamiento de Reinhart Koselleck, a los fines de reproblematizar el concepto de revolución.

11 “Terminar con los lamentos y pasar a la acción”, Compañero, año 1, nro. 10, 12 de agosto de 1963, p. 5.
} 
a reformas políticas, donde el "último grito de la modernización política era la organización corporativista" (p. 246). ${ }^{12}$

La entrevista antes mencionada se llevó a cabo un mes después de la elección presidencial de junio de 1963. El peronismo estuvo impedido de participar. No puede sorprender, entonces, que desde las páginas de Compañero apareciera como la única vía para concretar la tan ansiada revolución el involucramiento de los trabajadores en el gobierno. Este era un sentir que repercutió desde comienzos del mismo año, como lo muestra, por ejemplo, la entrevista al dirigente sindical "duro", Jorge Di Pascuale: "la elección no puede expresar todo el sentir de la masa, porque se han instrumentado todos los medios para asfixiarla" (Baschetti, 2012, p. 244).

Asimismo, desde el semanario se establecieron un conjunto de políticas que debían implementarse en el escenario futuro que se abriría con el regreso de Perón. Frente al aumento del precio de la carne y la escasez del producto que se vivía en la Argentina de Illia, se abogaba no solo por la "[f]ijación de precios máximos y control de cambios" sino también por una "solución de fondo": la nacionalización de los frigoríficos y la expropiación de los mayores invernadores. ${ }^{13}$ En lo relativo a los contratos petroleros, por ejemplo, se pedía por la "expropiación de las empresas" y la "nacionalización integral de la industria del petróleo". ${ }^{14}$ Luego, respecto al régimen de tenencia de tierras y al papel que en ella tenía la "oligarquía", se exigía el planteamiento y la ejecución de una "reforma agraria profunda y la expropiación sin indemnización de las clases parasitarias del campo". ${ }^{15}$

Como puede percibirse, estos postulados lindaban muy de cerca con lo propuesto tan solo unos años antes en Huerta Grande. En contrapartida, nula mención se hacía en Compañero respecto a cualquier camino al socialismo o a una colectivización de la actividad económica. Si bien no puede negarse la gravitación de la Cuba revolucionaria en las ideas políticas y económicas del periodo, debería matizarse cualquier tipo de asociación sin más del peronismo que se autodefinía revolucionario con la vía de desarrollo socialista. En este sentido, puede repararse, por ejemplo, en una nota sobre la movilización de FOTIA ante la acusación de "comunismo" a los obreros del azúcar tucumano: “La revolución que hizo Fidel Castro en Cuba, fue para Cuba. La que haga el

\footnotetext{
12 Algo similar anota Mónica Gordillo (2007). Un lugar común entre finales de los cincuenta y principios de los sesenta fue la aceptación por un cambio de estructuras. Por un lado, "se necesitaba modificar la estructura política, la frágil ‘democracia burguesa' que mantenía marginada a la fuerza política mayoritaria, contribuyendo a perder confianza en el sistema democrático-representativo” (p. 336). Por el otro, también se insistió en la necesidad de cambiar la estructura económica y social que llevase a un sistema donde los sectores populares gobernasen de forma efectiva. Para la historiadora, este imaginario coincidía con la apuesta por "luchar contra el imperialismo personificado en los monopolios y en las grandes empresas extranjeras" (Gordillo, 2007, p. 336).

13 "Qué hacer con nuestras carnes", Compañero, año 1, nro. 25, 12 de diciembre de 1963, p. 4.

14 “Petróleo. El gobierno en la conciliación”, Compañero, año 2, nro. 50, 9 de julio de 1964, p. 3.

15 "Expropiar a la oligarquía. Objetivo revolucionario", Compañero, año 2, nro. 69, 20 de octubre de 1964, p. 4.
} 
peronismo en la Argentina, será para la Argentina; aquella cubana y la nuestra peronista y argentina". ${ }^{16}$

Claro que esta no es la postura de Cooke. Como anota Norberto Galasso (2004), Cooke empezó a insistir a Perón acerca del camino que estaba transitando la Revolución Cubana, "pasando de la revolución nacional a la socialista" (p. 154), expropiando las empresas norteamericanas de teléfonos, electricidad, refinerías de petróleo y 36 ingenios azucareros. Al decir de Bozza (2001), el otrora delegado personal de Perón creía que debía enlazarse la experiencia del peronismo posterior a 1955 con el influjo que comenzaba a ejercer la Revolución Cubana. Tanto era así que, sentencia el historiador, para los militantes fundacionales del peronismo revolucionario, "el castrismo y el peronismo, eran dos modalidades nacionales de la lucha revolucionaria continental" (p. 140). Esto último era algo que el propio Perón ayudaba a anudar. Por ejemplo, en su carta al "Bebe" del 31 de julio de 1960, decía el exiliado que la "fuerza de Cuba, como la de todos los que luchamos por la liberación" estaba vinculada a que la línea intransigente del peronismo "coincide con el desarrollo histórico y la evolución” (Cooke, 2014 [1972], p. 452$).{ }^{17}$

Retomando a Compañero, ¿qué sentido tenía el término revolución para el semanario, si ella no involucraba socialismo? En su último editorial antes de la salida de circulación, Valotta decía:

Perón significa la Revolución contra el sistema de explotación e ignominia que mantienen sobre la clase trabajadora la oligarquía vernácula y sus amos, el capitalismo financiero internacional. Su presencia física en el país desataría la lucha activa y violenta de las masas por su liberación (...) Los militantes de la línea revolucionaria peronista (...) debemos continuar pacientemente, obstinadamente, la labor de esclarecimiento de las bases, mostrando cómo dentro de las instituciones del régimen, de su 'legalidad' tramposa y fraudulenta, no se pueden solucionar ni uno solo de los problemas de explotación, desocupación, injusticia y entrega que soporta la clase trabajadora. Cómo NO HAY SALIDA PÁCIFICA. Cómo EL ÚNICO CAMINO ES LA REVOLUCIÓN. Cómo la Revolución no se improvisa ni es una explosión súbita, sino que por el contrario es un trabajo de agitación, esclarecimiento y organización que hay que realizar día a día. ${ }^{18}$

\footnotetext{
16 "Los incas: un imperio socialista", Compañero, año 2, nro. 55, 14 de julio de 1964, p. 7.

17 Estas palabras de Perón deben ser leídas, no obstante, en el marco que ofrecía la Revolución Cubana previamente a la "Invasión de Bahía de Cochinos" de abril de 1961 y su abrazo al socialismo. Este episodio no solo desencantó a un sector de los nacionalistas, como lo atestigua el caso de Marcelo Sánchez Sorondo y su semanario Azul y Blanco (María Valeria Galván, 2014). Asimismo, tampoco produjo meramente tensiones al interior de la novel escisión del Partido Socialista de 1958, el Partido Socialista Argentino (María Cristina Tortti, 2009). En el peronismo, por ejemplo, la deriva socialista de la Revolución Cubana llevó al propio Cooke, unos meses después de los episodios de "Bahía de Cochinos", a manifestarle a Perón su malestar ante el escaso involucramiento del movimiento peronista en la defensa del proceso cubano. Para el "Bebe", el peronismo dejó "esa bandera en manos de los comunistas argentinos, dándoles un excelente argumento interno e internacional para revalidar sus títulos de antiimperialistas", y quitándole vigor a la intensión del peronismo por mostrarse como otra cosa respecto a la usual imagen de un "movimiento reaccionario, militarista y clerical" (Cooke, 2014 [1972], p. 483). El autor agradece a uno de sus evaluadores anónimos este señalamiento.

18 “Levantar bien alto las banderas del retorno", Compañero, año 3, nro. 79, 1era quincena de abril de 1965, p.1.
} 
Las primeras líneas son ya una confesión de fe: Perón era simbolizado como la revolución. Esto es, el retorno del caudillo "desataría la lucha activa y violenta de las masas" contra lo que era identificado como un "sistema de explotación e ignominia". ${ }^{19}$ Perón venía a significar una revolución que descreía que las "instituciones del régimen" para paliar los problemas que pesaban sobre los trabajadores. En este preciso sentido, entonces, el "único camino es la revolución", en tanto y en cuanto la "'legalidad' tramposa y fraudulenta" del sistema político no resolvía "ni uno solo de los problemas de explotación, desocupación, injusticia y entrega". La revolución no era un camino pacífico, debiendo llevar a los elementos comprometidos con ella a trabajar en la "agitación, esclarecimiento y organización", desestimando cualquier concepción que pretenda presentar a la revolución, que significa la vuelta de Perón a la Argentina nuevamente, como un hecho improvisado. Es así, entonces, como puede coincidirse con Marcelo Raimundo (2001): Compañero buscó delinear "formas de lucha y organización diferentes a las propuestas por la burocracia", a las que consideraba como las más "adecuadas a los objetivos revolucionarios" (p. 221). Parafraseando el viejo apotegma peronista, solo la organización de los elementos comprometidos con la revolución podría vencer la resistencia del sistema político-económico.

\section{La hora (liberacionista) de los pueblos (en armas)}

El 31 de marzo de 1964 se inició una revuelta militar contra el presidente del Brasil João Goulart que terminó en su destitución y posterior exilio. El mando del país fue delegado por el Congreso al Jefe del Estado Mayor del Ejército y líder de los sublevados, Humberto de Alencar Castelo Branco, el 15 de abril. Para Tulio Halperín Donghi (2007 [1969]), la intención de Goulart de extender el sufragio a los analfabetos, permitir la sindicalización de los campesinos y la adopción de un programa de reforma agraria, encendieron las alarmas de los oficiales militares, contribuyendo al desapego constitucional. A esto se sumaba el viaje del por aquel entonces presidente a la China comunista.

En Compañero, el golpe de Estado en territorio brasileño fue tratado in extenso. Además de entrevistar a Goulart y a su consejero, Leonel Brizola, exiliados ambos en Uruguay, las repercusiones del golpe ocuparon un lugar destacado en los editoriales de Valotta. $\mathrm{Al}$ respecto, señalaba el editor:

El golpe reaccionario brasileño no es un hecho aislado en América Latina (...) [Fue una] decisión del imperialismo yanqui de contener a sangre y fuego los anhelos de liberación

\footnotetext{
${ }^{19}$ Según Emilio De Ipola (1983), la de Perón siempre fue una "misión de paz". El caudillo "no viene a traer el escándalo al mundo: viene, por el contrario, munido de autoridad de Jefe, a mediar en un conflicto en tren a agravarse, con el objetivo de restablecer el equilibrio de la balanza" (p. 146). Esto se correspondería, asimismo, con el famoso punto 11 de las "Veinte verdades peronistas": el peronismo busca la unión nacional y no la lucha. Sin embargo, ya ha sido marcado sin amagues que la paz puede perfectamente ser la forma que toma la ruptura en el peronismo (Melo, 2009).
} 
de los pueblos latinoamericanos (...) [N]o quedaba [para los Estados Unidos] otra alternativa que la violencia, después del fracaso de la gran mistificación que fue la Alianza para el Progreso, ante la conciencia creciente de los pueblos (...) El proceso de Brasil ha servido para dejar en claro la nueva política yanqui, cuyo próximo objetivo es la Argentina. ${ }^{20}$

El quiebre constitucional acaecido en territorio brasileño debía importar a la Argentina, aseguraba Valotta, no solo porque era el próximo objetivo de la política norteamericana después del traspié de la Alianza para el Progreso, sino también debido a que constituía una decisión deliberada del "imperialismo yanqui" para ponerle coto a los procesos de "liberación de los pueblos latinoamericanos" utilizando la violencia. Pero, ¿qué significaba aquí el vocablo liberación? Además de los innegables tintes marxistas que lo recorren, ${ }^{21}$ algo más se esconde. Al respecto, Hannah Arendt (2012 [1963]) sugirió que, en la concepción revolucionaria, la liberación hacía referencia al pathos de la rebelión y la toma del poder de todos aquellos pobres y humildes que a lo largo de la historia se percibieron a sí mismos como sometidos al capricho de los poderosos. Algo de esto reverbera en la concepción de liberación de Compañero: liberación en tanto subversión del orden de opresión por parte de los humildes que, parafraseando a Marx, no tenían nada más para perder que su condición de oprimidos. Volviendo al extracto del editor del semanario, el golpe no debía ser tomado como "un hecho aislado". Era una herramienta más de aquellos que trabajaron durante años para que los pueblos de Latinoamérica permanecieran aislados entre sí. Sin embargo, continuaba Valotta en otro editorial:

Hoy, a la opresión común que nos asfixiaba, se agrega otro factor de unión y de esperanza: la lucha de todos por la emancipación total y la autodeterminación. Por eso, recogemos con entusiasmo las palabras en favor de la unidad de las fuerzas populares latinoamericanas de los dirigentes brasileños (...) El proceso de liberación de Nuestra América está en marcha y es emocionante encontrarnos y reconocernos como hermanos después de tantos años de aislamiento. Desde el Caribe hasta el Cono Sur, pasando por todo el Continente Sudamericano, se habla un mismo lenguaje: el de la revolución latinoamericana. ${ }^{22}$

El lazo entre las distintas experiencias que estaban llevándose a cabo en América Latina estaría dado por la lucha por la "emancipación total y la autodeterminación". Esto es, la unidad del conjunto heteróclito de fenómenos estaba en su combate a los "imperialismos". No está lejana esta idea respecto a lo señalado por Guillermina Georgieff (2008): lo que era común a una gama de autores tan disímiles como Rodolfo

\footnotetext{
20 “La política del garrote", Compañero, año 2, nro. 42, 14 de abril de 1964, p. 1.

${ }^{21} \mathrm{Si}$ bien este trabajo no va a valerse de las reflexiones marxistas para pensar la cuestión de la liberación, debe mencionarse aquí, por ejemplo, el trabajo que Herbert Marcuse (1969). Sin ser un examen exclusivamente teórico sobre la "liberación", este ensayo de Marcuse ahonda en los retos que presentó para la izquierda socialista, que abogaba por prácticas "liberacionistas", las derivas represivas y/o reformistas del capitalismo a final de los años sesenta. Para ampliar más sobre la temática de la liberación, pero en clave filosófica, se sugiere Enrique Dussel (1977).

22 “La revolución latinoamericana”, Compañero, año 2, nro. 47, 19 de mayo de 1964, p. 1.
} 
Puiggrós, Milcíades Peña, Juan José Hernández Arregui o John William Cooke era el "rescate y la defensa de un perfil histórico de independencia y solidaridad con proyección continental" que permitiera una "segunda emancipación" y, claro está, también la "liberación de los explotados y oprimidos" (p. 243). Valotta, en el extracto citado, se refería claramente a ello. Ese "proceso de liberación" que estaba llevándose a cabo en América Latina permitía a los pueblos reconocerse y redimirse "después de tantos años de aislamiento". Reconocimiento mediado por un mismo idioma: el de la "revolución latinoamericana".23

Aquí puede hacerse un señalamiento: la "inscripción latinoamericanista" de la Argentina no es una novedad de los años sesenta. Como muy bien anota Edgardo Manero (2014), la reivindicación nacional, inscripta en el marco de la "Patria Grande", se instaló tempranamente en la escena política argentina. Es el caso de, por ejemplo, Manuel Urgarte, quien ya en 1912 esbozaba una idea de latinoamericanidad y de "Patria Grande". Asimismo, la Reforma Universitaria de 1918 constituyó otro momento significativo de apelación a una identidad latinoamericana. Otro caso que debe ser mencionado es el de la Fuerza de Orientación Radical de la Joven Argentina (FORJA) y el primer punto de la declaración aprobada por su asamblea constituyente en 1935. En el peronismo, por otro lado, la integración latinoamericana constituyó una de sus reivindicaciones fundamentales. La concepción latinoamericanista, señala Manero (2014), se consolidó "como pertenencia y afirmación de sí a escala universal" (p. 315), en donde la autonomía nacional se constituía a partir de proyecciones continentales. En este sentido, la necesidad de afirmar lazos entre las naciones del subcontinente que esgrimía el peronismo en el poder estaba orientada a maximizar la capacidad de negociación con las grandes potencias.

Avanzando más en el tiempo, la cuestión de la "revolución latinoamericana" es marcada por Germán Gil (1989) en su lectura de Cristianismo y Revolución, publicación de finales de los años sesenta y ligada al nacimiento de la agrupación político-militar Montoneros. Para el historiador argentino, a través de las páginas de la publicación:

[Se] nos ponen a la vista, en sucesión vertiginosa, las luchas campesinas, sindicales, insurreccionales y guerrilleras de Argentina, Perú, Guatemala, Vietnam, Brasil y otras partes del Tercer Mundo; la contigüidad de las páginas crea las impresiones de cercanía y simultaneidad (...) El lector argentino cobra conciencia de lo local de su circunstancia, frente a otros cientos de regiones que, como puntualmente informa la revista, sostienen luchas guerrilleras. Así se crea la imagen de un enorme espacio convulsionado, donde la violencia de los oprimidos achica los espacios y los ensancha -paradójicamente- hacia la lucha continental y, en menor medida, hacia los pueblos oprimidos del Tercer Mundo ( $p$. $52)$.

\footnotetext{
${ }^{23}$ ¿No resuena aquí aquella característica que Koselleck ([1979] 1993) identificó para el campo conceptual de la revolución, que la revolución política tenga como telos una emancipación social que transforme las estructuras?
} 
En un sentido similar, en Compañero también aquellos fenómenos identificados con la "liberación nacional" y los focos guerrilleros en los países africanos, asiáticos y latinoamericanos pretendían crear esas "impresiones de cercanía y simultaneidad", donde la inminente revolución tocaría las puertas de la Argentina a su tiempo. Se buscaba edificar, también en el semanario editado por Valotta, la imagen de un "enorme espacio convulsionado", en el cual la "excepcionalidad argentina" se encontraba diluida dentro del marco que ofrecía la "lucha continental" de los "pueblos oprimidos del Tercer Mundo". Así, por ejemplo, desde las páginas del seminario vocero del MRP, se sostenía que "Venezuela, Colombia, Centroamérica, son los tantos escenarios de un fermento revolucionario (...) [en el que] todo el continente se convertirá en un gigantesco campo de batalla". ${ }^{24}$ Debe tenerse en cuenta que, como señala Gordillo (2007), la prédica nacionalista de la década de los sesenta estuvo relacionada con el fenómeno de la liberación nacional. Fenómeno que, sostiene la autora, adquirió un sentido doble. Por un lado, significó la lucha contra el imperialismo, por una nación que fuese independiente y soberana en sus relaciones con otros países. Por el otro, implicaba afirmar el respeto y el bienestar de los sectores populares. En sintonía similar, para Ehrlich (2012), el “espacio desde el cual el tópico antiimperialista se formulaba se había ensanchado de tal modo geográficamente que llegó a abarcar países cuya historia era remota y diversa" de la Argentina (p. 181). Esto permitía a Compañero, por caso, sostener que las experiencias argelina y cubana son "semillas que hoy se multiplican en los cuatro costados del mundo". ${ }^{25}$

Esta es una cuestión capital para comprender los procesos de configuración y transformación de las identidades políticas. Sin caer en salvavidas teóricos omnicomprensivos como puede ser la idea de un "clima de época", de lo que aquí se trata es más bien de pensarlo como un contexto que, como marcan las ciencias de la comunicación y la lingüística, involucra el agrupamiento de específicas circunstancias de tiempo y lugar, donde el acto de comunicación se está llevando a cabo. Parafraseando la intuición de Carl Schmitt (2005 [1962]), se trataría de un contexto político-universal que es algo más que el apoyo técnico, político o económico que un tercero puede brindar a un grupo X. Es, principalmente, un halo de legitimidad a partir del cual se transforma la identidad de ese grupo $X$, mediado por los esquemas y cosmovisiones de ese tercero. Tomar en consideración este marco contextual permite comprender por qué pueden algunos elementos encontrarse y otros no. Esto es, ayuda a comprender por qué se produjo la articulación entre los distintos elementos que forman un discurso en particular. Tener presente y examinar esta superficie discursiva de emergencia permite entender mejor, por ejemplo, la equiparación que Compañero hizo de la situación social y política argentina con la de países tan diferentes como Venezuela, Vietnam o el Congo.

\footnotetext{
24 "Colombia: hambre y fraude", Compañero, año 2, nro. 29, 13 de enero de 1964, p. 2.

25 "Esta es la hora de los pueblos", Compañero, año 3, nro. 77, 2da quincena de febrero de 1965, p. 3.
} 
O, también, la asimilación que realizó entre la figura del guerrillero del Viet Cong, Nguyen Troi, con Vallese y los fusilados en José León Suarez en 1956.26

Por aquellos primeros años de los sesenta, señala Ehrlich (2012), el panteón de héroes en el cual se inscribía la tradición peronista "parece combinar su énfasis de siempre en la historia patria (...) con la construcción de un espacio supranacional, el de los movimientos africanos y luego, latinoamericanos, lo cual relegitima la actualidad del peronismo en el país" (p. 183). Para la historiadora, el tópico de la "ocupación" o la invasión permitía señalar una novedad en el peronismo posterior a 1955: un conjunto de "referencias más contemporáneas que históricas, más espaciales que temporales, donde determinados sectores del peronismo pretenden inscribir su legitimidad y significado vigentes de su partido" (Ehrlich, 2012, p. 184). Sin embargo, es interesante remarcar que en Compañero se produjo también una recuperación de lo que podría denominarse "gestas y patriotas de Latinoamérica": una sección homónima publicada entre los números 63 y 73 donde se analizaban fenómenos tales como la "Revolución Mexicana" (1910), la nacionalización del petróleo mexicano (1938), la "Revolución Boliviana" (1952), la Revolución Cubana (1959), además de detenerse en figuras como las de Jorge Eliecer Gaitán de Colombia, Augusto Cesar Sandino de Nicaragua o Getulio Vargas de Brasil. Así, entonces, lo que en el semanario se encuentra es más bien una convivencia de referencias contemporáneas -léase, las "luchas de liberación nacional" en Asia, África y parte de América Latina- e históricas -como son esos supuestos hitos y personajes de la historia Latinoamericana del siglo XX-. Ambas referencias permitían a Compañero constituir el carácter revolucionario del peronismo no solo apelando a ejemplos de la actualidad sino también a los que el pasado latinoamericano parecía ofrecer. Quiere señalarse, al parecer, que América Latina fue un enorme espacio convulsionado desde siempre. Es así que cobran real sentido las preguntas retóricas que se hace en el número 77: “¿qué pueden importarles a los pueblos que vienen incubando su rebelión en centurias de sufrimiento, los meses o los años que pueda prolongarse la lucha? ¿Qué importa el tiempo cuando se tiene seguridad en el triunfo?". 27

Lo que se ha dicho hasta el momento puede contribuir a comprender la pequeña columna que aparece en el número 17 del semanario. En "Perón: la hora de los pueblos", se dice:

El Jefe del Movimiento Mayoritario ha fijado recientemente la actitud a adoptar frente al proceso mundial(...) [F]rente a dichas grandes fuerzas mundiales del capitalismo y del comunismo soviético debe alzarse la gran corriente que reúna y sirva a todos los pueblos que hoy luchan por su liberación (...) Aquello que va a determinar el proceso que vivimos y darle forma, es la lucha entre el imperialismo y aquellos países que luchan por su liberación (...) Como una marea incontenible, las luchas de liberación que jalonan todo lo largo de este siglo, fueron tomando organicidad, coherencia y un empuje tal, que

\footnotetext{
26 "Van Troi asesinado por los yanquis será vengado", Compañero, año 3, nro. 71, 3 de noviembre de 1964, p. 2.

27 "Esta es la hora de los pueblos", Compañero, año 3, nro. 77, 2da quincena de febrero de 1965, p. 3.
} 
lentamente fue e irá venciendo inexorablemente a las fuerzas de represión imperialista como ya ha sucedido en tantos países. Nunca como ahora resulta acertada la definición del Movimiento frente al momento político mundial, e indica una vez más las características de movimiento revolucionario profundamente nacional y antiimperialista del peronismo. ${ }^{28}$

Esta pequeña columna anticipaba de alguna manera aquello que Perón plasmará en su libro de 1968 "La hora de los pueblos". Por un lado, la cuestión de que "luchas de liberación" son las que caracterizaban el momento presente. Por el otro, que ellas se posicionaban frente a los sistemas capitalistas y comunistas. No obstante, este posicionamiento respecto a los dos bloques dominantes no debe verse como una novedad absoluta de estos años en el discurso de Perón. Ya en sus clases de filosofía dictadas en el año 54 en la Escuela Superior Peronista el caudillo señalaba el camino alternativo de la Tercera Posición peronista, que "no es capitalista ni comunista", sin por ello significar una "abstención" o desentendimiento de los "problemas políticos, económicos y sociales que afronta el mundo contemporáneo" (Perón, 1974 [1954], pp. 270 y 271). Retomando el extracto antes expuesto, nada dice la columna, como sí sucederá en su libro del año $68,^{29}$ del tipo de configuración ideológica que presentaban esos "países que luchan por su liberación". Se auguraba, empero, que este conjunto iría tomando "organicidad" y "coherencia", produciendo la derrota final de las "fuerzas de represión imperialista". Asimismo, la definición de Perón, el hecho de que el máximo exiliado y líder del movimiento se pronunciara en favor de las luchas de liberación de los países independizados de Asía y África, servía a Compañero para remarcar el carácter "nacional", "revolucionario" y "antiimperialista" que creían observar en el peronismo.

\section{Los vicios de una "seudodemocracia"}

El 14 de marzo del año 1965 se llevaron a cabo elecciones para renovar 96 de los 192 escaños de la Cámara de Diputados. La oposición neoperonista se hizo con 37 bancas. Para César Tcach (2007), la nueva composición del Congreso a raíz de los diputados electos reflejaba el peso que tenía el sindicalismo liderado por Vandor. Con Paulino Niembro como presidente del bloque peronista, los conflictos al interior del peronismo no tardaron en adquirir mayor aspereza. Lo que quedó en claro tras los comicios, como anota Virginia Persello (2007), fue que las dos fuerzas mayoritarias, el peronismo y el radicalismo, se asentaban una sobre un mito -la fortaleza de los sectores populares- y la otra sobre una opción, pero "ninguna representaba al país 'verdadero'" (p. 219). Luego de las legislativas de marzo, las críticas hacia el gobierno de Illia arreciaron. Estas se inscribían, como sugieren César Tcach y Celso Rodríguez (2006), en el marco de un

\footnotetext{
28 "Perón: la hora de los pueblos", Compañero, año 1, nro. 17, 16 de octubre de 1963, p. 2.

29 Según lo expresaba en esta obra, para aquellos que no comulgaban con el sistema capitalista y la democracia liberal, se abrían dos opciones: un "socialismo internacional y dogmático", el soviético, y un "socialismo nacional", que encontraba a sus apologetas en los movimientos de liberación nacional de Asia, África y Medio Oriente (Perón, 2012 [1968] p. 18).
} 
deterioro flagrante del prestigio hacia los partidos políticos, el parlamento y a la democracia.

Estas críticas al sistema democrático imperante en la Argentina de principios de los sesenta estaban presentes, lógicamente, en las páginas de Compañero. Tómese como ejemplo lo siguiente:

[Tras la agresión norteamericana a Panamá en 1964] [t]odas las frases hipócritas y huecas son abandonadas para dejar paso al verdadero lenguaje de los mezquinos intereses capitalistas, el de la violencia. Queda en claro, entonces, que la 'libertad' y la 'democracia' que propagan no son medios para que las mayorías se hagan oír y ejecuten su voluntad, ni principios inmutables, sino válvulas de escape para los anhelos de soberanía de las masas, simples instrumentos que garantizan el control del poder por las minorías vinculadas a los intereses capitalistas. ${ }^{30}$

La experiencia de los pueblos de Latinoamérica indica que las elecciones son simples 'formalidades' de la seudodemocracia, que sirve para encubrir el carácter opresor y de explotación de los regímenes dominados por el imperialismo yanqui y las clases reaccionarias internas. Cuando deja de cumplir este papel y las clases opresoras ven peligrar sus posiciones, pasa como en nuestro país, en Brasil, en Perú o en cualquier otro país de América Latina: la seudodemocracia abandona sus 'formalidades' y emplea la violencia abierta y descarada contra el pueblo. ${ }^{31}$

Los extractos pueden hacer intervenir una cuestión más que interesante desarrollada nuevamente por Arendt (2012 [1963]): la reflexión sobre la hipocresía. Al decir de la teórica alemana, los revolucionarios franceses declararon una guerra contra la hipocresía que percibían en la sociedad del siglo XVIII. Desde este punto de vista, la Revolución de 1789 fue presentada como la explosión de un núcleo incorruptible que quebraba lo que se consideraba como una carcasa de decadencia y decrepitud. Para los revolucionarios franceses, sentenció Arendt (2012 [1963]), la “Revolución ofrecía la oportunidad de arrancar la máscara de la hipocresía de la faz de la sociedad francesa, de poner de manifiesto su podredumbre", derribando, a fin de cuentas, el halo corrupto y volviendo a poner sobre la superficie "la faz inmaculada y honesta del peuple" (p. 140). Asimismo, esta "guerra contra la hipocresía" estuvo presente en aquellos que la autora califica como glorificadores de la violencia por la violencia misma (Arendt, 2015 [1972]). Autores como Sorel, Pareto y Fanon, a partir del intento por desenmascarar la hipocresía del enemigo, sus maquinaciones y manipulaciones engañosas que le permitían dominar sin apelar a medios violentos, abogaban todos ellos por "provocar la acción incluso al riesgo de la aniquilación para que pueda surgir la verdad" (Arendt, 2015 [1972], p. 168).

Algo de esto está presente en las palabras de Compañero sobre la democracia. Como se desprende de los extractos citados, las instituciones del sistema democrático, tal y como existían en estos primeros años setenta, no eran más que "simples 'formalidades'". Así, por un lado, detrás de cualquier fraseología sobre la "libertad" y sobre la

\footnotetext{
30 “Panamá no está solo", Compañero, año 2, nro. 30, 21 de enero de 1964, p. 1.

31 “También en Chile Braden contra el pueblo", Compañero, año 2, nro. 61, 25 de agosto de 1964, p. 8.
} 
"democracia", lo que se escondía era la violencia. Esto es, las "simples formalidades de la seudodemocracia", como eran las elecciones, encubrían la raíz violenta que servía al sistema político-económico para sostenerse. En este sentido, la agresión norteamericana al pueblo panameño en enero de 1964 o el golpe de Estado en Brasil del mismo año eran entendidos como momentos en los que ese "poder de las minorías vinculadas a los intereses capitalistas" abandonaba sus "frases hipócritas y huecas" y se lanzaba a la lisa y llana violencia. Ella parecía representar la "sustancia verdadera" de esa "seudodemocracia" frente a las palabras "vacías" como elecciones, libertades y democracia. Asimismo, esta asociación entre el sistema democrático que imperaba en la Argentina posperonista y su carácter falso e hipócrita está presente en el Perón de Los vendepatria (1974 [1958]). Aseguraba allí el caudillo que, tras el golpe de 1955, no interesaba tanto ser realmente democrático como parecerlo. Se trataba, en cambio, de una "simulada democracia que ni sienten ni practican" (p. 149). Esto mismo encuentra Humberto Cucchetti (2010) en su análisis de la agrupación juvenil peronista Guardia de Hierro en los primeros años sesenta: una fuerte crítica al sistema democrático representativo y a los partidos políticos, que involucraba, además, reprobar cualquier tentativa de transformar al peronismo en un partido político del sistema.

Lo dicho hasta aquí debería ser concebido en el marco legal que ofrecía la Argentina posperonista en el acaecer de la "Libertadora". El gobierno formado tras la "Revolución" de septiembre de 1955 ensayó un ambicioso proyecto para "suprimir todo vestigio de totalitarismo para restablecer el imperio de la moral, de la justicia, del derecho, de la libertad y de la democracia", como rezaban las Directivas básicas del gobierno revolucionario lanzadas después del golpe palaciego de Aramburu en noviembre de 1955 (Citado en Rouquié, 1982, p. 129). Proyecto cuyo epítome fue el famoso decreto-ley 4161 de marzo de 1956 que prohibía la mera mención de Perón o de su segunda esposa, Eva Perón, so pena de treinta días a seis años de prisión. Al decir de Julio César Melón Pirro (2014), la “proscripción del partido y de las instituciones del peronismo constituyeron la base del sistema político inaugurado en 1955" (p. 149).

Aquí, no obstante, debe tenerse la precaución de no caer en aserciones como las de Rouquié (1982) -“En lugar de 'desperonizar' a los trabajadores, la Revolución Libertadora 'reperonizó' a grandes sectores populares" (p. 141)- o de Gordillo (2007) [La política "desperonizadora" del 55] "contrariamente al efecto buscado (...) produjo un refuerzo de la identidad peronista" (p. 333)-. Argumentos causalistas como estos pueden llevar a lo que se denomina, en el ámbito de la lógica, a la falacia cum hoc ergo propter hoc: una conexión que no es tal entre dos o más fenómenos que se dan al mismo tiempo. Por ejemplo, asumir, como parecen hacerlo los autores antes citados, que fue el fracaso de la política por "desperonizar" la sociedad argentina la que condujo a un reencuentro entre la tradición peronista y los sectores popular, y que ese fracaso también rigidizó la identidad peronista. En este sentido, si bien es cierto que las políticas proscriptivas aplicadas por el gobierno de Aramburu influyeron en las transformaciones de la identidad peronista en el periodo, de ello no debería seguirse una relación causal 
A=B. En otras palabras, la proscripción fue condición necesaria pero no suficiente de esas mutaciones.

Retomando el hilo, el periodo que se abrió con el exilio de Perón fue testigo, en el medio de las medidas proscriptivas, de la construcción de partidos que buscaron disputarle su electorado a Perón: los partidos neoperonistas. Muchos de estos, como sugieren María Arias y Raúl García Heras (2004 [1993]), trataron de llevar adelante una política conciliatoria de parte del gobierno de la "Revolución Libertadora", bajo la hipótesis de que cualquier crecimiento de los neoperonistas se traduciría inmediatamente en la anulación o eliminación de Perón del escenario político-electoral. Claramente, como lo muestran las sucesivas compulsas electorales del periodo 1957 1965, aquello quedó simplemente en un deseo. Para decirlo con los autores antes mencionados, los políticos neoperonistas, contando no solo con un margen más amplio para maniobrar sino también con una figura del calibre de Vandor tras bambalinas, no pudieron horadar la capacidad de reconocimiento que para una porción no menor de las huestes peronistas continuaba teniendo la jefatura carismática de Perón. En otras palabras, al menos para el momento de que aquí se trata en lo referente al liderazgo peronista, 32 el "carisma de Perón no estaba tan disperso y la mística peronista estaba más viva entre las masas de lo que Vandor y otros dirigentes neoperonistas habían pensado" (Arias y García Heras, 2004 [1993], p. 121).

En definitiva, entonces, en Compañero, el sistema político-económico es endilgado con una serie de vicios: corrupción, decadencia, falsedad. Ahora bien, ¿cuáles son las tareas de la militancia peronista ante este panorama? ¿Qué debía reemplazar a ese sistema en "crisis"? Dos extractos del semanario pueden ayudar a responder estas preguntas:

$[\mathrm{N}] \mathrm{o}$ son hoy los sectores populares los que deben deponer aspiraciones, sino todas las clases o sectores que se han turnado en el poder y han demostrado su incapacidad de conducir los destinos de la Nación. Hoy sólo pueden gobernar los auténticos representantes del pueblo. Para quebrar la trampa y terminar de una vez por todas con las maniobras de las fuerzas retrógradas, hay que pasar a la ofensiva (...) Debemos convencernos que de estas elecciones [Presidenciales de 1963] prefabricadas no surgirá ninguna solución. ${ }^{33}$

Hoy es evidente que la libertad de la oligarquía es la opresión de los trabajadores y del pueblo. Siendo esto así, un régimen popular es incompatible con concesiones democráticas a las fuerzas del privilegio. (...) Las proscripciones nos parecen un acto de sinceridad política de la oligarquía. Vemos en ellas un testimonio de realismo político, un precedente valiosísimo, una escuela práctica de democracia verdadera ¿Cuál es la fórmula política a que debería ajustarse un verdadero régimen popular? La misma que hoy pone en práctica la oligarquía contra el pueblo, pero aplicada contra la oligarquía misma. Impedir que los enemigos del país puedan atacar al pueblo. Garantizar por todos los medios la

\footnotetext{
32 El liderazgo carismático de Perón recorrió innumerables caminos a lo largo de sus dieciocho años de exilio, cambiando en los diversos momentos las condiciones que permitían mantener una relación carismática: el reconocimiento, la corroboración y la emotividad (Max Weber 2008 [1922]). Para el caso que ocupa a este artículo, la figura de Vandor puso en tensión el carisma de Perón.

33 "Un solo camino", Compañero, año 1, nro. 4, 28 de junio de 1963, p. 1.
} 
imposibilidad de todo 'retornisno' a 'épocas felizmente superadas'. Sólo que el pueblo hará esto sin vanas hipocresías, invocando su derecho histórico a gobernar. ${ }^{34}$

El primero de los extractos citados, uno de los editoriales de Valotta que antecede a las elecciones presidenciales de 1963, establecía tajantemente la necesidad de que los "auténticos representantes del pueblo", los "sectores populares", pasen a encabezar una ofensiva frente a las "fuerzas retrógradas", esas habían mostrado total incompetencia para gobernar la Argentina. Aparece aquí una revalorización de las instancias intermedias que "verdaderamente" puedan representar al pueblo. El mencionado "pasar a la ofensiva", sin embargo, no estaba relacionado con participar de las elecciones, ya que "no surgirá ninguna solución" de ellas. ¿De dónde o cómo surgiría la solución al atolladero en que se encontraba el peronismo? La principal nota política del mismo número -el segundo de los extractos- parece esbozar una respuesta: poner en práctica un régimen de exclusión pero que sea el reverso exacto de aquel que imperaba desde 1955. Lo que se pedía en Compañero, en este sentido, no solo era un gobierno que pudiera defender al pueblo de sus enemigos, sino también uno que imposibilitara "todo 'retornismo'"; que impidiera, a fin de cuentas, que un gobierno como el de la "Revolución Libertadora" pudiese tomar el poder nuevamente. Únicamente el pueblo era capaz de hacerlo, debido a su falta de hipocresía y también porque en él residía el "derecho histórico a gobernar".

Se está aquí ante aquello que marcó Daniela Slipak (2015) para un periodo posterior: una disputa contra los elementos que caracterizaban a los regímenes demócratasliberales. Aquí el significado que toma el concepto de revolución en el semanario involucraba arrancar de forma definitiva esa "máscara de hipocresía" que recubría presuntamente al sistema político-económico, poniendo de manifiesto la "podredumbre" y la "corrupción" que lo envolvía. Era esta una "revolución social", producto de la lucha por la toma del poder y el regreso de Perón, que pretendía recuperar el cariz honesto e inmaculado del pueblo. ${ }^{35} \mathrm{Al}$ respecto, nada ilustra mejor esta denuncia -falsedad/corrupción del sistema vs. autenticidad/honestidad del pueblo- que la crítica a la penetración cultural del imperialismo y el desvelamiento de su decadencia, frente al carácter "incontaminado" del pueblo (Georgieff, 2008).

\section{Conclusiones}

Este artículo buscó analizar una de las formas en que se pensó el hecho revolucionario en el peronismo de comienzos de los años sesenta, a partir del examen de una publicación ligada al sindicalismo "duro" y a los sectores "combativos", el semanario Compañero. Además de ser una publicación más referenciada que analizada en profundidad, esta publicación permite ahondar en un periodo capital para la Argentina y para el movimiento liderado por Perón: la década del sesenta.

\footnotetext{
34 "El derecho histórico del pueblo a gobernar", Compañero, año 1, nro. 4, 28 de junio de 1963, p. 4.

35 “Las bases se oponen a la claudicación”, Compañero, año 2, nro. 39, 24 de marzo de 1964, p. 5.
} 
En las páginas del semanario, el término revolución asumía la forma de un objetivo deseado o una meta anhelada, instancia a partir de la cual se podía introducir la novedad erigiendo un nuevo origen. En concreto, tres tópicos fueron tratados en esta indagación por los contornos que tomó el significante revolución en Compañero.

En primer lugar, la interrogación acerca del supuesto carácter socialista de la revolución. Ella involucraba, por un lado, el trazado de nuevas estructuras económicas, sociales y políticas para Compañero. Asimismo, por otro, la revolución debía devolver el papel presuntamente protagónico que las masas habían tenido en los hechos revolucionarios acaecidos anteriormente en la Argentina. El semanario enunciaba un conjunto de políticas que debía seguir la restitución de Perón en el gobierno, con grandes similitudes con los programas de La Falda y Huerta Grande de 1957 y 1962, respectivamente. Esto permitió matizar aquellas afirmaciones que ven en el peronismo revolucionario de estos años una "vía socialista" o propuestas socializantes. En el caso de Compañero, por ejemplo, está ausente cualquier reivindicación de tipo socialista.

El segundo de los tópicos analizados fue el de la liberación. Es decir, la concepción que destacaba el acto de rebelión y toma del poder por parte de los humildes y explotados que suponía el proceso revolucionario. En el semanario se produjo una suerte de asimilación entre la situación de guerra de liberación y focos guerrilleros en los países llamados del Tercer Mundo y la que se vivía en la propia Argentina. Esta asimilación marca una interesante manifestación del proceso de constitución y transformación de las identidades políticas: la resignificación de conflictos nativos a la luz de dinámicas foráneas. A esto apuntaba, por ejemplo, la equiparación que hacía Compañero entre las muertes de Nguyen Troi y de Vallese o la asimilación del ensayo guerrillero en Salta con la situación venezolana o congoleña. Una cuestión relevante que surgió del análisis fue la expansión geográfica y temporal del panteón de héroes latinoamericanos que puede encontrarse en el semanario.

Finalmente, el tercer y último tópico que dejó el acercamiento al concepto de revolución como apuesta futura fue el de la hipocresía. Para Compañero, toda la estructura legal/electoral del sistema político-económico no era más que una formalidad vacía. En este sentido, entonces, uno de los envites principales de Compañero fue el de edificar un régimen político que no solo otorgara un lugar privilegiado a los sectores populares, sino que contara además con mecanismos institucionales que impidieran un desenlace como el que tuvo el gobierno peronista el 16 de septiembre de 1955.

Este trabajo no pretende cerrar la indagación sobre los contornos que tomó el término revolución para el movimiento peronista en la década del sesenta. Un análisis como el que se llevó adelante aquí no puede dar cuenta de forma total de la pluralidad de significaciones, de las múltiples continuidades y torsiones que ese concepto tomó en el peronismo de aquellos años. En este sentido, entonces, posteriores trabajos deberán complementar las conclusiones derivadas del artículo aquí propuesto, comparándolas, por ejemplo, con otras lecturas acerca del fenómeno revolucionario que otras "líneas" peronistas elaboraron en el periodo. Pueden guiar estos futuros trabajos preguntas 
como: ¿en qué se diferenciaba la noción delineada en Compañero de la apuesta revolucionaria "por el cambio de estructuras" del sindicalismo peronista? ¿Cómo entendían y explicaban los sectores políticos peronistas a sus adherentes o electores los intentos de reorganización y participación en las elecciones? ¿Qué contornos tomó la “Tercera Posición" en las distintas vertientes del peronismo en estos años, sea la sindical o la política? En definitiva, numerosos son los interrogantes que pueden hacerse y que ulteriores investigaciones deberán tratar de responder.

\section{Referencias bibliográficas:}

Aboy Carlés, G. (2001). Las dos fronteras de la democracia argentina. La reformulación de las identidades políticas de Alfonsín a Menem. Rosario: Homo Sapiens.

Anderson, P. (1984). Modernidad y revolución. Leviatán (16), 99-114.

Anderson, P. (2010). Two revolutions. New Left Review (61), 55-90.

Arendt, H. (2012 [1963]). Sobre la revolución. Madrid: Alianza.

Arendt, H. (2015 [1972]). Crisis de la república. Buenos Aires: Cuenco de Plata.

Arias, M. y García Heras, R. (2004 [1993]). Carisma disperso y rebelión: los partidos neoperonistas. En S. Amaral y M. B. Plotkin (Ed.), Perón: del exilio al poder (pp. 89-160). Sáenz Peña: Eduntref.

Baschetti, R. (2012). Documentos de la Resistencia Peronista 1955-1970. Vol. I. Buenos Aires: De la Campana.

Bozza, J. (2001). El peronismo revolucionario. Itinerario y vertientes de su radicalización. 1959-1969. Sociohistórica (9-10), 135-169.

Bozza, J. (2014). La resignificación revolucionaria del peronismo y sus protagonistas durante la etapa de la proscripción. En M. C. Tortti (Ed.), La nueva izquierda argentina (1955-1976) (pp. 59-82). Rosario: Prohistoria.

Calello, O. y Parcero, D. (1984). De Vandor a Ubaldini. Buenos Aires: CEAL.

Carman, F. (2015). El poder de la palabra escrita. Revistas y periódicos argentinos (1955 - 1976). Buenos Aires: Biblioteca Nacional.

Cooke, J. W. (2014 [1972]). Correspondencia Perón-Cooke. Buenos Aires: Colihue.

Cucchetti, H. (2010). Combatientes de Perón, herederos de Cristo. Buenos Aires: Prometeo.

Davidson, N. (2013). Transformar el mundo: revoluciones burguesas y revolución social. Barcelona: Pasado \& presente.

De Ipola, E. (1983). Ideología y discurso populista. Buenos Aires: Folios.

Dussel, E. (1977). Filosofía de la liberación. México DF: EDICOL.

Ehrlich, L. (2012). Intransigentes, duros y revolucionarios. Variaciones en la cultura política peronista entre 1955 y 1963 (Tesis de doctorado). Universidad de Buenos Aires, Buenos Aires.

Gaitán, C. (2014). La Resistencia. El peronismo que yo he vivido. Buenos Aires: Ciccus.

Galasso, N. (2004). Cooke. De Perón al Che. Una biografía política. Buenos Aires: Nuevos Tiempos. 
Galván, M. V. (2014). El Nacionalismo de derecha argentino a comienzos de la década del sesenta y la Revolución Cubana: lecturas del semanario Azul y Blanco. Sociohistórica (34), 1-17.

Georgieff, G. (2008). Nación y revolución. Itinerarios de una controversia en Argentina (1960 - 1970). Buenos Aires: Prometeo.

Gil, G. (1989). La izquierda peronista. Buenos Aires: CEAL.

Gordillo, M. (2007). Protesta, rebelión y movilización: de la Resistencia a la lucha armada, 1955-1973. En D. James (Dir.), Nueva historia argentina. Tomo IX Violencia, proscripción y autoritarismo (1955-1976) (pp. 329-380). Buenos Aires: Sudamericana.

Halperín Donghi, T. (2007 [1969]). Historia contemporánea de América Latina. Buenos Aires: Alianza.

Hilb, C. y Lutzky, D. (1984). La nueva izquierda argentina. 1960-1980. Buenos Aires: CEAL. James, D. (1990). Resistencia e integración. Buenos Aires: Sudamericana.

Koselleck, R. (1993 [1979]). Futuro pasado. Barcelona: Paidós.

Laclau, E. (1996). Emancipación y diferencia. Buenos Aires: Nueva Visión.

Laclau, E. y Mouffe, C. (2006 [1985]). Hegemonía y estrategia socialista. Buenos Aires: FCE. Manero, E. (2014). Nacionalismo(s), política y guerra(s) en la Argentina plebeya (1945-1989). San Martín: UNSAM-Edita.

Marcuse, H. (1969). Ensayo sobre la liberación. México DF: Cuadernos de Joaquín Mortiz. McGuire, J. (2004 [1993]). Perón y los sindicatos: la lucha por el liderazgo peronista. En S. Amaral y M. B. Plotkin (Ed.), Perón: del exilio al poder (pp. 161-203). Sáenz Peña: Eduntref.

Melo, J. (2009). Fronteras populistas. Populismo, peronismo y federalismo entre 1943 y 1955 (Tesis de doctorado). Universidad de Buenos Aires, Buenos Aires.

Melón Pirro, J. C. (2014). Normalización partidaria en tiempos de proscripción. El peronismo entre 1963 y 1965. En J. C. Melón Pirro y N. F. Quiroga (Comps.), El peronismo y sus partidos. Tradiciones y prácticas políticas entre 1946 y 1976 (pp. 149-167). Rosario: Prohistoria.

Ollier, M. M. (1986). El fenómeno insurreccional y la cultura política argentina. Buenos Aires: CEAL.

Perón, J. D. (1974 [1958]). Los vendepatria. Buenos Aires: Liberación.

Perón J. D. (2012 [1968]). La hora de los pueblos. Buenos Aires: Fabro.

Persello, A. V. (2007). Historia del radicalismo. Buenos Aires: Edhasa.

Plotkin, M. B. (1991). Perón y el peronismo un ensayo bibliográfico. Estudios Interdisciplinarios de América Latina y el Caribe 2 (1), 1-16.

Raimundo, M. (2001). Compañero y los orígenes del Peronismo Revolucionario. Sociohistórica (8), 203-226.

Rouquiè, A. (1982). Poder militar y sociedad política en la Argentina. Tomo II 1943-1973. Buenos Aires: Emecé.

Schmitt, C. (2005 [1962]). Teoría del partisano. Buenos Aires: Struhart \& Cía.

Schneider, A. (2006). Los compañeros. Buenos Aires: Imago Mundi. 
Slipak, D. (2015). Las revistas montoneras. Buenos Aires: Siglo XXI.

Tcach, C. (2007). Obreros rebeldes, sexo y religión en el origen del peronismo cordobés.

En D. Macor y C. Tcach (Comps.), La invención del peronismo en el interior del país (pp. 17-62). Santa Fe: UNL.

Tcach, C., y Rodríguez, C. (2006). Arturo Illia: un sueño breve. Buenos Aires: EDHASA.

Tortti, M. C. (2009). El "viejo" partido socialista y los orígenes de la "nueva" izquierda. Buenos Aires: Prometeo.

Wasserman, F. (2008). Revolución. En N. Goldman (Ed.), Lenguaje y revolución. Conceptos políticos clave en el Río de la Plata, 1780-1850 (pp. 159-174). Buenos Aires: Prometeo.

Weber, M. (2008 [1922]). Economía y sociedad. México DF: FCE.

Para citar este artículo:

Funes Andrés N. (2019). Ruptura, liberación y necesidad. El semanario Compañero y una lectura sobre la revolución en los sesenta del peronismo. Anuario de la Escuela de Historia Virtual 15, 27-50. 